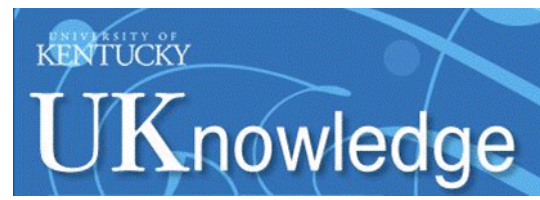

University of Kentucky

UKnowledge

6-18-2010

\title{
High-Throughput Experimental Studies to Identify miRNA Targets Directly, with Special Focus on the Mammalian Brain
}

\author{
Peter T. Nelson \\ University of Kentucky, pnels2@email.uky.edu \\ Marianthi Kiriakidou \\ University of Kentucky \\ Zissimos Mourelatos \\ University of Kentucky \\ Grace S. Tan \\ University of Kentucky \\ Mary $\mathrm{H}$. Jennings \\ University of Kentucky, mary.jennings@uky.edu
}

See next page for additional authors

Follow this and additional works at: https://uknowledge.uky.edu/pathology_facpub

Part of the Neurosciences Commons, and the Pathology Commons

Right click to open a feedback form in a new tab to let us know how this document benefits you.

\section{Repository Citation}

Nelson, Peter T.; Kiriakidou, Marianthi; Mourelatos, Zissimos; Tan, Grace S.; Jennings, Mary H.; Xie, Kevin; and Wang, Wang-Xia, "High-Throughput Experimental Studies to Identify miRNA Targets Directly, with Special Focus on the Mammalian Brain" (2010). Pathology and Laboratory Medicine Faculty Publications. 21.

https://uknowledge.uky.edu/pathology_facpub/21

This Article is brought to you for free and open access by the Pathology and Laboratory Medicine at UKnowledge. It has been accepted for inclusion in Pathology and Laboratory Medicine Faculty Publications by an authorized administrator of UKnowledge. For more information, please contact UKnowledge@lsv.uky.edu. 
High-Throughput Experimental Studies to Identify miRNA Targets Directly, with Special Focus on the Mammalian Brain

\author{
Digital Object Identifier (DOI) \\ https://doi.org/10.1016/j.brainres.2010.03.108 \\ Notes/Citation Information \\ Published in Brain Research, v. 1338, p. 122-130. \\ Copyright (C) 2010 Elsevier B.V.
}

The copyright holder has granted the permission for posting the article here.

This manuscript version is made available under the CC-BY-NC-ND 4.0 license

http://creativecommons.org/licenses/by-nc-nd/4.0/.

\title{
Authors
}

Peter T. Nelson, Marianthi Kiriakidou, Zissimos Mourelatos, Grace S. Tan, Mary H. Jennings, Kevin Xie, and Wang-Xia Wang 


\title{
High-throughput experimental studies to identify miRNA targets directly, with special focus on the mammalian brain
}

\author{
Peter T. Nelson, MD PhD, Marianthi Kiriakidou, MD, Zissimos Mourelatos, MD, Grace S. Tan, \\ PhD, Mary Jennings, Kevin Xie, and Wang-Xia Wang, PhD \\ Department of Pathology and Division of Neuropathology, University of Kentucky Medical Center \\ and Sanders-Brown Center on Aging, University of Kentucky, Lexington, KY, 40536
}

\begin{abstract}
We review the pertinent literature on methods used in high-throughput experimental identification of microRNA (miRNA) "targets" with emphasis on neurochemical studies. miRNAs are short regulatory non-coding RNAs that play important roles in the mammalian brain. The functions of miRNAs are related to their binding of RNAs including mRNAs. Since mammalian miRNAs tend to bind to target mRNAs via imperfect complementarity, understanding exactly which target mRNAs are recognized by which specific miRNAs is a challenge. Based on early experimental evidence, a set of "binding rules" for miRNAs has been described. These have focused on the 5' "seed" region of miRNAs binding to the 3' untranslated region of targeted mRNAs. Bioinformaticians have applied these algorithms for theoretical miRNA target prediction. To date, the different computational methods are not in agreement with each other and do not explain all miRNA targets as defined using high-throughput experimental methods. We consider these latter techniques which identify putative miRNA targets directly. Each experimental approach involves specific assumptions and potential technical pitfalls. Some of these direct experimental methods for miRNA target identification have used co-immunoprecipitation (RIP-Chip and others) and transfection-based experimental design. Topics related to experimentally identified miRNA targets are discussed, with special emphasis on studies pertinent to the mammalian brain.
\end{abstract}

\section{Introduction}

MicroRNAs (miRNAs) are 22 nucleotide (nts) non-coding RNAs that play fundamental roles in the most animal tissues including the human brain (Ambros, 2004; Kosik, 2006).

Functionally, miRNAs "target" mRNAs through partial hybridization, leading to changes in the rate of cognate polypeptide formation. miRNAs interact with mRNAs within microribonucleoparticles (miRNPs) which contain both protein and RNAs (Mourelatos et al., 2002). Also in miRNPs, Argonaute (AGO) proteins bind directly to mature miRNAs. Four paralogous mammalian AGO proteins (AGOs 1-4) help orchestrate miRNA activities (Carmell et al., 2002; Hammond, 2005; Sasaki et al., 2003). A single miRNA, in association with AGO proteins, may target hundreds of different mRNAs. In the majority of cases, miRNAs silence gene expression by translational repression and RNA degradation. There are many molecular

(C) 2010 Elsevier B.V. All rights reserved.

Corresponding Author: Peter T. Nelson MD PhD, Department of Pathology, Division of Neuropathology, and the Sanders-Brown Center on Aging, Rm 311, Sanders-Brown Center, 800 S. Limestone, University of Kentucky, Lexington, KY, 40536-0230, pnels2@email.uky.edu, wk ph \# (859) 257-1412 x 254.

Publisher's Disclaimer: This is a PDF file of an unedited manuscript that has been accepted for publication. As a service to our customers we are providing this early version of the manuscript. The manuscript will undergo copyediting, typesetting, and review of the resulting proof before it is published in its final citable form. Please note that during the production process errors may be discovered which could affect the content, and all legal disclaimers that apply to the journal pertain. 
mechanisms that occur downstream of the miRNA:mRNA interaction, and these mechanisms may differ in particular species, tissues, and cells (Iwasaki and Tomari, 2009; Kiriakidou et al., 2007; Liu et al., 2008; Morris, 2008; Parker et al., 2006; Saetrom et al., 2007; Tan et al., 2009a).

The goal of this review is to discuss studies that use high-throughput techniques to identify putative miRNA targets (PmiTs), with emphasis on studies pertinent to the human brain. For the sake of this review, a PmiT is a mRNA that is bound to by a specific miRNA with decreased cognate polypeptide as a result (whatever the exact downstream mechanism). The reason that we use the word "putative" is that the miRNA targets identified by these techniques generally need to be validated using other, more labor-intensive, methods. Since each experimental method has its own assumptions, strengths, and weaknesses, these data need to be assessed with critical scrutiny. There is multi-layer regulatory complexity in vivo, including different levels of transcript processing and modifications, multiple subtypes of noncoding RNA, complex RNA binding protein biochemistry, and many other biological signals. These are of course distinct from the technical experimental limitations affecting researchers who attempt to identify physiological miRNA targets. Note that many of the studies that are referred to were in systems not directly related to the mammalian brain. We assume that many of the lessons learned from those systems can have at least indirect relevance to the many researchers who are thinking of experimental strategies to study mammalian brain PmiTs.

\section{The "binding rules"}

Just as important as discovering individual miRNAs' targets is characterizing the over-arching biochemical principles that govern how miRNAs interact with target mRNAs with particular reference to the molecules' sequence complementarity. We term these the "binding rules" for the sake of brevity. Binding rules are pivotal because if one understood completely how miRNAs interact with mRNAs then it would be possible to predict confidently the strength of individual interactions. An extensive amount of work has been performed in this area and further studies are ongoing (see for example (Alexiou et al., 2009b; Bartel, 2009; Hon and Zhang, 2007; Kiriakidou et al., 2004; Rajewsky, 2006)).

In animals, miRNAs tend to bind via imperfect complementarity making target prediction difficult. Nonetheless, certain tendencies have emerged. Studies to date have focused primarily on specific sequence determinants of the miRNA and the mRNA:

1> The " 5 ' seed" (nts \#2-7 from the 5' end) portion of miRNAs

2> The 3 ' untranslated (UTR) portion of mRNAs

According to these ideas (with the support of a large amount of experimental data including recent high-throughput proteomics data (Baek et al., 2008; Orom and Lund, 2009; Selbach et al., 2008)) a given PmiT is "downregulated" if a 6nts sequence in its 3'UTR is complementary to a 5' seed region of a co-expressed miRNA. These binding rules are by no means absolute but they provide a common point of consensus among many experimental and computational experts in the field.

\section{Computational methods: progress and limitations}

If the above binding rules were applicable in every instance, then mammalian miRNA target prediction would have been solved and all computational methods would be essentially identical. But such is not the case. Computational methods for miRNA target prediction are in constant refinement. The evolution of computational methods occurs at many levels including within individual groups' methodology and also due to new groups and methodologies coming (literally) on-line. For reviews on the subject of computational miRNA target prediction, see 
(Alexiou et al., 2009a; Barbato et al., 2009; Berezikov et al., 2005; Brown and Sanseau, 2005; Maziere and Enright, 2007; Miranda et al., 2006; Robins et al., 2005; Watanabe et al., 2007).

Some actual miRNA targets are not predicted or explained using existing computational methods. There is also some question whether any "one size fits all" computational prediction algorithm is valid that ignores potential idiosyncrasies of different organisms, cells, tissues, genes, and miRNA families. Well-documented miRNA:mRNA pairs have been described that would not be predicted by most current computational methods (Didiano and Hobert, 2006; Rigoutsos, 2009). Even within a mRNA's 3'UTR there are many complexities in terms of sequence determinants, tertiary structure, protein interactions, and/or alternative splicing events. Finally, miRNA-based regulation is not generally an "all-or-none" phenomenon (Bartel, 2009; Su et al., 2009; Ying and Lin, 2005) and the ability for computational methods to predict the strength gradations of miRNA binding and/or miRNA "activity" is currently debated.

These concerns do not diminish the relevance and importance of computational approaches to miRNA target prediction. Computational algorithms are and will remain an important tool for miRNA researchers. However, in order to help refine and strengthen these algorithms in the context of small regulatory RNA science, more experimental studies are required.

\section{Methods for simultaneous identification of multiple putative miRNA targets}

High throughput methods for identifying PmiTs have been invented utilizing a variety of experimental technologies and contexts (Orom and Lund, 2009). An overview of these studies is presented (Table 1). However, a few common denominators have emerged. First, most methods work through isolating target mRNAs that are bound to miRNAs. Secondly, there must be some high-throughput method for correlating and cataloging the miRNA-bound mRNAs that are (relatively) specific to individual miRNAs. The target profiling techniques have involved various types of arrays, deep sequencing, and proteomics techniques.

To isolate mRNAs that are bound by miRNAs, many studies have used coimmunoprecipitation (co-IP) based methods, often with downstream microarrays to profile the target mRNAs (this approach can be termed "RIP-Chip"(Keene et al., 2006)). For these experiments, an antibody has tended to be used in the co-IP which means that a protein must be recognized. The co-IPed protein usually has been AGO protein(s), which directly embrace pre-miRNAs and mature miRNAs along with target mRNAs. Some studies have employed "tagged" AGO proteins. For a list of PmiT studies using co-IP approaches, along with pertinent additional details, see Table 1 .

miRNA transfection is another technique that has been widely used in experiments for highthroughput identification of PmiTs. miRNA transfection usually requires some sort of membrane perturbation that enables the small polynucleotides to enter the cells and to become incorporated into the miRNA processing machinery. This technique is especially relevant to PmiT prediction because it allows researchers to control for the dominantly expressed miRNA in the cell of interest. By comparing the target mRNA repertoire in cells with different miRNAs transfected, the PmiTs can be predicted to be due to that differential miRNA expression. Note that in some of the studies (Table 1), both co-IP and transfections were utilized. It should also be noted that transfection or overexpression of exogenous miRNAs resembles a straightforward siRNA experiment with unpredictable downstream events (see below). For this reason, miRNA depletion approaches (Cheng et al., 2005;Horwich and Zamore, 2008;Krutzfeldt et al., 2005; Orom et al., 2006) could provide effective additional functional information about physiological target sites. 
Where can one access experimentally derived PmiTs, and, what insights have the abovementioned studies provided about PmiTs? Some public domain web-based data repositories are available that provide data on experimentally identified PmiTs (for example, see (Hammell et al., 2008; Hsu et al., 2006; Lall et al., 2006; Sethupathy et al., 2006)). Note that there are many more data about experimentally identified PmiTs within papers and in "supplemental materials" on published works such as those in Table 1. In the future we may be able to incorporate all these data in meta-level research projects, along with some sort of methods to compare strengths and weaknesses of various approaches. We discuss below some of the important themes and interesting questions that have emerged from the very large amount of data in these important studies.

\section{Common assumptions in high-throughput PmiT identification studies}

The studies enumerated in Table 1 provide data directly relevant to how miRNAs target mRNAs and which miRNAs bind to which mRNAs. However, there is some question as to whether those studies adequately capture and convey the complexity of their subject. Here are a handful of common assumptions that probably merit some attention in terms of interpreting prior studies and designing future ones.

\section{Generalizability of findings in individual experimental systems}

Much of the gene expression regulation (transcription, translation, splicing, etc.) machinery are similar even across phylogenetically divergent species. It is thus unlikely, for example, that an entirely distinct miRNA regulatory mechanism would evolve in the course of primate evolution. On the other hand, there are some key differences in how miRNAs work across different animal species, as there are quite different paradigms at work in plants. Some aspects of miRNA biochemistry have been shown to be species-specific (Berezikov et al., 2006; Landthaler et al., 2008; Mourelatos et al., 2002; Zhang et al., 2008). Specific mammalian tissue and cell types (sperm cells being the best example) have their own subtypes of small regulatory RNAs and their own AGO-like proteins (Aravin et al., 2006). It seems as though the miRNA molecular machinery is a platform with an exceptional potential for complex and multimodal gene expression regulation that includes transcriptional and translational control. For example, some - but not all - human miRNAs and AGO proteins are now known to reside in the nucleus and bind DNA although nuclear miRNA biochemistry is still poorly understood (Guang et al., 2008; Kim and Rossi, 2009; Tan et al., 2009a). We and others have hypothesized that the miRNAs and other noncoding RNA have served as a "complexity multiplier" in the evolution of the fantastically complex primate brain (Heimberg et al., 2008; Mehler and Mattick, 2007; Nelson and Keller, 2007). Thus, as our comprehension of the full potential of miRNA-based gene regulation expands, it is likely that some mechanisms will differ based on specific parameters related to species, cell types, developmental stages, environmental stimuli, etc.

\section{Physiological relevance of tumor cell lines}

Tumor cell lines have been a mainstay experimental context of studies that use high-throughput methods to identify new PmiTs (see Table 1). Clearly, there are extremely compelling reason to use these well-characterized, clonal cells for easily replicable hypothesis testing and robust data generation. However, there are also good reasons to reflect on the characteristics of tumor cell lines: they are neoplastic; they tend to have extensive chromosomal abnormalities; and they are selected for particular characteristics (robustness, transfectability, plate adherence, etc) that are divorced from physiological normalcy. Their very survival and passage in culture is evidence of stark differences relative to most normal cells. In sum, they are non-physiologic. Tumor cells tend to have suppression of miRNA expression and/or modification of miRNA processing proteins (Adams et al., 2009; Chung et al., 2009; Ciafre et al., 2005;Guo et al., 2009; Wijnhoven et al., 2007). Thus it is possible that an over-reliance on tumor cell line studies 
has introduced biases in the study of PmiTs: we may be missing entire physiological pathways and we may be witnessing evidence of some cancer-specific biochemical pathways of dubious correlation to that of healthy cells in situ. For most relevance to human brain, it may be best experimentally to try different clonal cell lines including human cells and cells with neuronal phenotype.

\section{Co-immunoprecipitation experiments with tagged Argonaute proteins}

At least a half-dozen of the important studies that have described experimentally derived PmiTs have used co-IP experiments with tagged AGO proteins (see Table 1). The protein tags have varied and include MYC, FLAG, and HA peptide tags. A common assumption underlying these studies is that the tagged AGO function analogously to the non-tagged AGO, or, if there is a difference, the tagged AGO does not systematically alter the distribution of miRNAs incorporated or mRNAs targeted. This is not necessarily a safe assumption. We have found that tagged AGO in some cancer cell lines may be loaded with fewer endogenous miRNAs (see Figure 1 and unpublished data). For some of the experiments, there is a possibility that this may introduce currently unknown systematic biases.

\section{Alternative miRNA mechanisms and stability of Argonaute-miRNA-mRNA interactions}

Most of the methods used to derive PmiTs experimentally with high-throughput methods require for there to be some sort of stable association between AGO, miRNA, and targets. These miRNP complexes are then washed until only the miRNP remains and then the targets are profiled. It is very possible that a subset of miRNAs and/or targets have more transient interactions that do not survive the washing steps. These might introduce another source of bias. As a potential example of this, we have found that miR-107 seems to target both GRN and BACE1 mRNAs; however, only GRN mRNA is found enriched in the AGO-miRNP after washing (see below). Some methods of high-throughput PmiT identification would side-step the dependence on stable miRNA:mRNA interaction, most notably the HITS-CLIP method that uses ultraviolet (UV) cross-linking and downstream identification of miRNA-bound mRNAs (see below). However, even this method has some technical assumptions.n In the outstanding mouse brain HITS-CLIP study, the miRNA most frequently UV "CLIPed" was mmu-miR-30e, which is not known to be among the top 10 most frequent brain miRNAs (Chi et al., 2009).

\section{Downregulation after miRNA transfection is due to specific targeting by the transfected MiRNA}

miRNA transfections lead to a large number of downstream changes including transcriptional regulation, widespread splicing changes, and others (see for example the work of (Khan et al., 2009; Makeyev et al., 2007)). These downstream effects, not directly linked to miRNA function, include dramatic shifts in the cellular mRNA and protein profiles. Thus secondary expression pattern changes are admixed with the primary mRNA targeting and it is a challenge to identify precisely which of these is which. Most studies note that predicted miRNA targets are enriched among the population of mRNAs downregulated after miRNA transfection (following the work of (Lim et al., 2005)). When we perform RIP-Chip experiments after miRNA transfections, we use downstream microarray analyses to assess for enrichment in AGO-miRNPs. Also, for each sample we also assess the lysates prior to the anti-AGO co-IPs. Thus we can detect the mRNAs that are changed in expression that are not enriched in the AGO-miRNPs. Consistently, we find that the large majority of mRNAs with altered expression after miRNA transfection are not found enriched in AGO-miRNPS according to the RIP-Chip analyses (see figure 2). These mRNA changes can be important, such as in the case of miR-125b targets identified by the Lodish Lab in neuroblastoma cells (Le et al., 2009). However, it may in some circumstances be incorrect to hypothesize that genes downregulated after miRNA 
transfected are AGO-bound direct miRNA targets. This concern provides another technical reason that the HITS-CLIP experimental approach is advantageous because it more directly identifies miRNA targets.

\section{"The binding rules"- - a reconsideration}

Another assumption that deserves critical scrutiny is that all miRNAs bind according to similar "rules". For example, since the 5, "seed" region of miR-124 and let-7a help to drive the specificity of those miRNAs to their target mRNAs, does the 5' seed also serve as the basis for all other miRNAs' binding? These assumptions seem quite appropriate when one considers the near universality of some other nucleic acid binding/activity determinants, such as TATA boxes, tRNA anti-codon sequences, and exon/intron junction-enriched sequences. However, there are also reasons to speculate that there could be variations in how individual miRNAs target their mRNAs. For example, the aggregate impact of 3'UTR A/U sequences, RNA tertiary structure, local RNA-binding proteins, and other idiosyncrasies could functionally determine particular miRNA targets. There are also important questions about the 3' portion of miRNAs. Why should a miRNA such as mir-124 or let-7a be absolutely conserved in every known animal if the mid-portion and 3' portion were not critical to its function? More to the point, there are now experimentally validated examples where the 3 ' portion of the miRNA are critical in mRNA targeting (Bartel, 2009).

If there are cell and tissue-specific determinants of specific miRNA and mRNA targets, there must be explanations for each biologic context. Testable hypotheses can be developed to explain differing apparent binding rules for individual miRNAs. miRNAs comprise only a small portion of miRNPs and other determinants such as the cell type-specific RNA binding proteins (AGO is only one of the many miRNP-associated proteins (Mourelatos et al., 2002)) and mRNA repertoire are critically important to gaining a fuller picture of miRNA targeting. Some miRNAs are spatially trafficked specifically to particular parts of the cell (nucleus versus cytoplasm, and dendrites versus axons, for example) and these compartmental differences might be accompanied by differing target determinants (Kye et al., 2007; Smalheiser, 2008a; Smalheiser and Lugli, 2009; Tan et al., 2009a).

\section{Brain-specific issues}

The issues of specialized cell compartmentalization and miRNA biochemistry may be supremely relevant in the mammalian brain. Nerve cell geometry -- with extreme distances between cytoplasmic compartments and the cell nuclei -- and the potential importance of highly localized activity-dependent translational control, are a few reasons why we and others have speculated that miRNAs and other noncoding RNAs may play special roles in the brain (Kosik and Krichevsky, 2005; Mehler and Mattick, 2007; Nelson et al., 2008). In the mammalian brain, synaptic structures may harbor special machinery for miRNA processing (Edbauer et al.; Smalheiser, 2008b). Roles for miRNAs in brain cell development and cell fate determination are well-established but this field is still in rapid flux (Dugas et al.; Fineberg et al., 2009; Krichevsky et al., 2006; Zhao et al.).

Relatively many of the prior studies using high-throughput methods to identify PmiTs have studied "nervous system-specific" miR-124 (see Table 1). However, fewer experiments have used an experimental system that included actual neurons, astrocytes, or other cell type associated with the brain. A column in Table 1 indicates specific papers that are relevant to high-throughput PmiT identification in mammalian brain-related cells. Space is insufficient to describe in detail each of the excellent papers on miRNA targets relevant to the mammalian brain, but several reports are discussed below. 
A particularly outstanding study on mouse brain (also referred to above) was from Robert Darnell's lab, using HITS-CLIP (Chi et al., 2009; Licatalosi et al., 2008). This approach allowed for direct identification of specific target sequences targeted in mammalian brain. The targeted sequences were identified using deep sequencing, rather than via microarray analyses such as are used in other experimental paradigms. The targeted sequences included mostly 3 ' UTR portions ( $40 \%$ of targets), but also coding sequences (CDS; $25 \%$ of targets), and introns ( $14 \%$ of targets). This study showed that there is a $~ 45-60$ nts AGO "footprint" of protected sequence when a mRNA is bound to by miRNAs and AGO. The HITS-CLIP data also provided the bases for some intriguing dissection of miR-124 targets in the mammalian brain. Further, the authors provided some "ternary maps" of AGO-miRNA-mRNA interactions related to the CLIPed miRNAs and mRNAs. These analyses provided some stimulating ideas about the pathways and neurochemical systems whose regulation is influenced by miRNAs in mammalian nervous systems. Surely we can anticipate future revelations about mammalian brain function and miRNA neurochemistry using this outstanding methodology.

We recently used anti-AGO RIP-Chip experiments in the H4 "glioneuronal" tumor cell line (Arnstein et al., 1974) after miRNA transfections for high-throughput identification of PmiTs (Wang et al., 2010). For these experiments, it was assumed that a tumor cell line has at least some physiological relevance, and that there is a stable interaction between AGO, miRNAs, and some target mRNAs. A subset of nervous system-enriched miRNAs were evaluated (miR-107, miR-124, miR-128, and miR-320). These experiments helped confirm that miRNAs have strong global impact on gene expression, because miRNA transfection led to large shifts in the mRNA repertoires. The changes included alteration in the miRNA machinery itself: miR-107 and miR-128, but not miR-320, miR-124, or a control miRNA, led to downregulation of AGO itself and a shift of miRNAs away from the AGO-miRNP.

Anti-AGO RIP-Chip experiments may also discover novel miRNA effects. We previously found that miR-107 is downregulated in Alzheimer's disease cerebral cortex (Wang et al., 2008); this observation was recently validated in a new dataset using well-characterized human brains (Wang et al, In Press). Having found that miR-107 targets BACE1 mRNA, which has also been validated by an independent laboratory (Davidson et al., 2009), we wanted to identify additional miR-107 targets using an unbiased high-throughput method. Surprisingly, using the anti-AGO RIP-Chip approach we found that $G R N$ mRNA is the strongest target for miR-107 in $\mathrm{H} 4$ cells despite the fact that computational algorithms did not predict binding (Wang et al, In Press). The discrepancy correlates with the observation that miR-107 targets sites in the CDS of GRN mRNA. This novel discovery may be relevant to neurodegenerative disease, brain inflammation, neurotrauma, and neoplasia in the mammalian brain and elsewhere. Future highthroughput PmiT studies will no doubt produce many such surprises as we refine our understanding of miRNA neurochemistry.

\section{Summary}

MiRNA research is a dynamic field with an ever-expanding experimental toolkit. New techniques have been invented and applied for direct, high-throughput experimental identification of PmiTs. These experiments help to characterize the miRNA binding rules in ever greater detail, which in turn help to guide computational algorithms. Many of these data are now available in public domain websites. Although direct experimental PmiT identification is extremely important, there are key assumptions made that should be considered carefully: for example, the generalizability of the results across different species and cell types; the relevance of tumor cell lines and/or tagged AGO proteins; the possibility of alternative AGO:miRNA mechanisms; and the possibility that different miRNAs can be processed by different binding proteins or cell compartments and thus according to different binding rules. 
Despite these caveats, PmiT identification can be vitally important, especially in the context of the mammalian nervous system where miRNAs may have special relevance.

\section{Acknowledgments}

This study was supported by grants R01 NS061933, K08 NS050110, and P01-NS051220 from NIH, Bethesda, MD, and NIRG-08-89917 from the Alzheimer's Association.

\section{Bibliography}

Adams BD, Claffey KP, White BA. Argonaute-2 expression is regulated by epidermal growth factor receptor and mitogen-activated protein kinase signaling and correlates with a transformed phenotype in breast cancer cells. Endocrinology 2009;150:14-23. [PubMed: 18787018]

Alexiou P, Maragkakis M, Papadopoulos GL, Reczko M, Hatzigeorgiou AG. Lost in translation: an assessment and perspective for computational microRNA target identification. Bioinformatics 2009a; 25:3049-3055. [PubMed: 19789267]

Alexiou P, Maragkakis M, Papadopoulos GL, Reczko M, Hatzigeorgiou AG. Lost in translation: an assessment and perspective for computational microRNA target identification. Bioinformatics 2009b; 25:3049-55. [PubMed: 19789267]

Ambros V. The functions of animal microRNAs. Nature 2004;431:350-5. [PubMed: 15372042]

Andachi Y. A novel biochemical method to identify target genes of individual microRNAs: identification of a new Caenorhabditis elegans let-7 target. RNA 2008;14:2440-51. [PubMed: 18824511]

Aravin A, Gaidatzis D, Pfeffer S, Lagos-Quintana M, Landgraf P, Iovino N, Morris P, Brownstein MJ, Kuramochi-Miyagawa S, Nakano T, Chien M, Russo JJ, Ju J, Sheridan R, Sander C, Zavolan M, Tuschl T. A novel class of small RNAs bind to MILI protein in mouse testes. Nature 2006;442:203-7. [PubMed: 16751777]

Arnstein P, Taylor DO, Nelson-Rees WA, Huebner RJ, Lennette EH. Propagation of human tumors in antithymocyte serum-treated mice. J Natl Cancer Inst 1974;52:71-84. [PubMed: 4544026]

Baek D, Villen J, Shin C, Camargo FD, Gygi SP, Bartel DP. The impact of microRNAs on protein output. Nature 2008;455:64-71. [PubMed: 18668037]

Barbato C, Arisi I, Frizzo ME, Brandi R, Da Sacco L, Masotti A. Computational challenges in miRNA target predictions: to be or not to be a true target? J Biomed Biotechnol 2009;2009:803069. [PubMed: 19551154]

Bartel DP. MicroRNAs: target recognition and regulatory functions. Cell 2009;136:215-33. [PubMed: 19167326]

Beitzinger M, Peters L, Zhu JY, Kremmer E, Meister G. Identification of human microRNA targets from isolated argonaute protein complexes. RNA Biol 2007;4:76-84. [PubMed: 17637574]

Berezikov E, Guryev V, van de Belt J, Wienholds E, Plasterk RH, Cuppen E. Phylogenetic shadowing and computational identification of human microRNA genes. Cell 2005;120:21-4. [PubMed: 15652478]

Berezikov E, Thuemmler F, van Laake LW, Kondova I, Bontrop R, Cuppen E, Plasterk RH. Diversity of microRNAs in human and chimpanzee brain. Nat Genet 2006;38:1375-7. [PubMed: 17072315]

Brown JR, Sanseau P. A computational view of microRNAs and their targets. Drug Discov Today 2005;10:595-601. [PubMed: 15837603]

Carmell MA, Xuan Z, Zhang MQ, Hannon GJ. The Argonaute family: tentacles that reach into RNAi, developmental control, stem cell maintenance, and tumorigenesis. Genes Dev 2002;16:2733-42. [PubMed: 12414724]

Cheng AM, Byrom MW, Shelton J, Ford LP. Antisense inhibition of human miRNAs and indications for an involvement of miRNA in cell growth and apoptosis. Nucleic Acids Res 2005;33:1290-7. [PubMed: 15741182]

Chi SW, Zang JB, Mele A, Darnell RB. Argonaute HITS-CLIP decodes microRNA-mRNA interaction maps. Nature 2009;460:479-86. [PubMed: 19536157]

Chung TK, Cheung TH, Huen NY, Wong KW, Lo KW, Yim SF, Siu NS, Wong YM, Tsang PT, Pang MW, Yu MY, To KF, Mok SC, Wang VW, Li C, Cheung AY, Doran G, Birrer MJ, Smith DI, Wong 
YF. Dysregulated microRNAs and their predicted targets associated with endometrioid endometrial adenocarcinoma in Hong Kong women. Int J Cancer 2009;124:1358-65. [PubMed: 19065659]

Ciafre SA, Galardi S, Mangiola A, Ferracin M, Liu CG, Sabatino G, Negrini M, Maira G, Croce CM, Farace MG. Extensive modulation of a set of microRNAs in primary glioblastoma. Biochem Biophys Res Commun 2005;334:1351-8. [PubMed: 16039986]

Davidson LA, Wang N, Shah MS, Lupton JR, Ivanov I, Chapkin RS. n-3 Polyunsaturated fatty acids modulate carcinogen-directed non-coding microRNA signatures in rat colon. Carcinogenesis 2009;30:2077-84. [PubMed: 19825969]

Didiano D, Hobert O. Perfect seed pairing is not a generally reliable predictor for miRNA-target interactions. Nat Struct Mol Biol 2006;13:849-51. [PubMed: 16921378]

Dugas JC, Cuellar TL, Scholze A, Ason B, Ibrahim A, Emery B, Zamanian JL, Foo LC, McManus MT, Barres BA. Dicer1 and miR-219 Are Required for Normal Oligodendrocyte Differentiation and Myelination. Neuron 65:597-611. [PubMed: 20223197]

Easow G, Teleman AA, Cohen SM. Isolation of microRNA targets by miRNP immunopurification. RNA 2007;13:1198-204. [PubMed: 17592038]

Edbauer D, Neilson JR, Foster KA, Wang CF, Seeburg DP, Batterton MN, Tada T, Dolan BM, Sharp PA, Sheng M. Regulation of synaptic structure and function by FMRP-associated microRNAs miR-125b and miR-132. Neuron 65:373-84. [PubMed: 20159450]

Fineberg SK, Kosik KS, Davidson BL. MicroRNAs potentiate neural development. Neuron 2009;64:303-9. [PubMed: 19914179]

Goff LA, Davila J, Swerdel MR, Moore JC, Cohen RI, Wu H, Sun YE, Hart RP. Ago2 immunoprecipitation identifies predicted microRNAs in human embryonic stem cells and neural precursors. PLoS ONE 2009;4:e7192. [PubMed: 19784364]

Guang S, Bochner AF, Pavelec DM, Burkhart KB, Harding S, Lachowiec J, Kennedy S. An Argonaute transports siRNAs from the cytoplasm to the nucleus. Science 2008;321:537-41. [PubMed: 18653886]

Guo J, Miao Y, Xiao B, Huan R, Jiang Z, Meng D, Wang Y. Differential expression of microRNA species in human gastric cancer versus non-tumorous tissues. J Gastroenterol Hepatol 2009;24:652-7. [PubMed: 19175831]

Hammell M, Long D, Zhang L, Lee A, Carmack CS, Han M, Ding Y, Ambros V. mirWIP: microRNA target prediction based on microRNA-containing ribonucleoprotein-enriched transcripts. Nat Methods 2008;5:813-9. [PubMed: 19160516]

Hammond SM. Dicing and slicing: the core machinery of the RNA interference pathway. FEBS Lett 2005;579:5822-9. [PubMed: 16214139]

Hausser J, Landthaler M, Jaskiewicz L, Gaidatzis D, Zavolan M. Relative contribution of sequence and structure features to the mRNA binding of Argonaute/EIF2C-miRNA complexes and the degradation of miRNA targets. Genome Res 2009;19:2009-20. [PubMed: 19767416]

Hayashida Y, Nishibu T, Inoue K, Kurokawa T. A useful approach to total analysis of RISCassociated RNA. BMC Res Notes 2009;2:169. [PubMed: 19706194]

Heimberg AM, Sempere LF, Moy VN, Donoghue PC, Peterson KJ. MicroRNAs and the advent of vertebrate morphological complexity. Proc Natl Acad Sci U S A 2008;105:2946-50. [PubMed: 18287013]

Hendrickson DG, Hogan DJ, Herschlag D, Ferrell JE, Brown PO. Systematic identification of mRNAs recruited to argonaute 2 by specific microRNAs and corresponding changes in transcript abundance. PLoS ONE 2008;3:e2126. [PubMed: 18461144]

Hendrickson DG, Hogan DJ, McCullough HL, Myers JW, Herschlag D, Ferrell JE, Brown PO. Concordant regulation of translation and mRNA abundance for hundreds of targets of a human microRNA. PLoS Biol 2009;7:e1000238. [PubMed: 19901979]

Hon LS, Zhang Z. The roles of binding site arrangement and combinatorial targeting in microRNA repression of gene expression. Genome Biol 2007;8:R166. [PubMed: 17697356]

Hong X, Hammell M, Ambros V, Cohen SM. Immunopurification of Ago1 miRNPs selects for a distinct class of microRNA targets. Proc Natl Acad Sci U S A 2009;106:15085-90. [PubMed: 19706460]

Horwich MD, Zamore PD. Design and delivery of antisense oligonucleotides to block microRNA function in cultured Drosophila and human cells. Nat Protoc 2008;3:1537-49. [PubMed: 18802435] 
Hsu PW, Huang HD, Hsu SD, Lin LZ, Tsou AP, Tseng CP, Stadler PF, Washietl S, Hofacker IL. miRNAMap: genomic maps of microRNA genes and their target genes in mammalian genomes. Nucleic Acids Res 2006;34:D135-9. [PubMed: 16381831]

Hsu RJ, Yang HJ, Tsai HJ. Labeled microRNA pull-down assay system: an experimental approach for high-throughput identification of microRNA-target mRNAs. Nucleic Acids Res 2009;37:e77. [PubMed: 19420057]

Iwasaki S, Tomari Y. Argonaute-mediated translational repression (and activation). Fly (Austin) 2009;3:204-6. [PubMed: 19556851]

Karginov FV, Conaco C, Xuan Z, Schmidt BH, Parker JS, Mandel G, Hannon GJ. A biochemical approach to identifying microRNA targets. Proc Natl Acad Sci U S A 2007;104:19291-6. [PubMed: 18042700]

Keene JD, Komisarow JM, Friedersdorf MB. RIP-Chip: the isolation and identification of mRNAs, microRNAs and protein components of ribonucleoprotein complexes from cell extracts. Nat Protoc 2006;1:302-7. [PubMed: 17406249]

Khan AA, Betel D, Miller ML, Sander C, Leslie CS, Marks DS. Transfection of small RNAs globally perturbs gene regulation by endogenous microRNAs. Nat Biotechnol. 2009

Kim DH, Rossi JJ. Transcriptional gene silencing using small RNAs. Methods Mol Biol 2009;555:11925. [PubMed: 19495692]

Kiriakidou M, Nelson PT, Kouranov A, Fitziev P, Bouyioukos C, Mourelatos Z, Hatzigeorgiou A. A combined computational-experimental approach predicts human microRNA targets. Genes Dev 2004;18:1165-78. [PubMed: 15131085]

Kiriakidou M, Tan GS, Lamprinaki S, De Planell-Saguer M, Nelson PT, Mourelatos Z. An mRNA m7G cap binding-like motif within human Ago2 represses translation. Cell 2007;129:1141-51. [PubMed: 17524464]

Kosik KS, Krichevsky AM. The Elegance of the MicroRNAs: A Neuronal Perspective. Neuron 2005;47:779-82. [PubMed: 16157272]

Kosik KS. The neuronal microRNA system. Nat Rev Neurosci 2006;7:911-20. [PubMed: 17115073]

Krichevsky AM, Sonntag KC, Isacson O, Kosik KS. Specific microRNAs modulate embryonic stem cellderived neurogenesis. Stem Cells 2006;24:857-64. [PubMed: 16357340]

Krutzfeldt J, Rajewsky N, Braich R, Rajeev KG, Tuschl T, Manoharan M, Stoffel M. Silencing of microRNAs in vivo with 'antagomirs'. Nature 2005;438:685-9. [PubMed: 16258535]

Kye MJ, Liu T, Levy SF, Xu NL, Groves BB, Bonneau R, Lao K, Kosik KS. Somatodendritic microRNAs identified by laser capture and multiplex RT-PCR. RNA 2007;13:1224-34. [PubMed: 17592044]

Lall S, Grun D, Krek A, Chen K, Wang YL, Dewey CN, Sood P, Colombo T, Bray N, Macmenamin P, Kao HL, Gunsalus KC, Pachter L, Piano F, Rajewsky N. A genome-wide map of conserved microRNA targets in C. elegans. Curr Biol 2006;16:460-71. [PubMed: 16458514]

Landthaler M, Gaidatzis D, Rothballer A, Chen PY, Soll SJ, Dinic L, Ojo T, Hafner M, Zavolan M, Tuschl T. Molecular characterization of human Argonaute-containing ribonucleoprotein complexes and their bound target mRNAs. RNA 2008;14:2580-96. [PubMed: 18978028]

Le MT, Xie H, Zhou B, Chia PH, Rizk P, Um M, Udolph G, Yang H, Lim B, Lodish HF. MicroRNA-125b promotes neuronal differentiation in human cells by repressing multiple targets. Mol Cell Biol 2009;29:5290-305. [PubMed: 19635812]

Licatalosi DD, Mele A, Fak JJ, Ule J, Kayikci M, Chi SW, Clark TA, Schweitzer AC, Blume JE, Wang X, Darnell JC, Darnell RB. HITS-CLIP yields genome-wide insights into brain alternative RNA processing. Nature 2008;456:464-9. [PubMed: 18978773]

Lim LP, Lau NC, Garrett-Engele P, Grimson A, Schelter JM, Castle J, Bartel DP, Linsley PS, Johnson JM. Microarray analysis shows that some microRNAs downregulate large numbers of target mRNAs. Nature 2005;433:769-73. [PubMed: 15685193]

Liu X, Fortin K, Mourelatos Z. MicroRNAs: biogenesis and molecular functions. Brain Pathol 2008;18:113-21. [PubMed: 18226106]

Makeyev EV, Zhang J, Carrasco MA, Maniatis T. The MicroRNA miR-124 promotes neuronal differentiation by triggering brain-specific alternative pre-mRNA splicing. Mol Cell 2007;27:43548. [PubMed: 17679093]

Maniataki E, Mourelatos Z. Human mitochondrial tRNAMet is exported to the cytoplasm and associates with the Argonaute 2 protein. RNA 2005;11:849-52. [PubMed: 15872185] 
Maziere P, Enright AJ. Prediction of microRNA targets. Drug Discov Today 2007;12:452-8. [PubMed: 17532529]

Mehler MF, Mattick JS. Noncoding RNAs and RNA editing in brain development, functional diversification, and neurological disease. Physiol Rev 2007;87:799-823. [PubMed: 17615389]

Miranda KC, Huynh T, Tay Y, Ang YS, Tam WL, Thomson AM, Lim B, Rigoutsos I. A pattern-based method for the identification of MicroRNA binding sites and their corresponding heteroduplexes. Cell 2006;126:1203-17. [PubMed: 16990141]

Morris KV. RNA-mediated transcriptional gene silencing in human cells. Curr Top Microbiol Immunol 2008;320:211-24. [PubMed: 18268846]

Mourelatos Z, Dostie J, Paushkin S, Sharma A, Charroux B, Abel L, Rappsilber J, Mann M, Dreyfuss G. miRNPs: a novel class of ribonucleoproteins containing numerous microRNAs. Genes Dev 2002;16:720-8. [PubMed: 11914277]

Nelson PT, Keller JN. RNA in brain disease: no longer just "the messenger in the middle". J Neuropathol Exp Neurol 2007;66:461-8. [PubMed: 17549006]

Nelson PT, Wang WX, Rajeev BW. MicroRNAs (miRNAs) in neurodegenerative diseases. Brain Pathol 2008;18:130-8. [PubMed: 18226108]

Nonne N, Ameyar-Zazoua M, Souidi M, Harel-Bellan A. Tandem affinity purification of miRNA target mRNAs (TAP-Tar). Nucleic Acids Res. 2009

Orom UA, Kauppinen S, Lund AH. LNA-modified oligonucleotides mediate specific inhibition of microRNA function. Gene 2006;372:137-41. [PubMed: 16503100]

Orom UA, Lund AH. Experimental identification of microRNA targets. Gene. 2009

Parker JS, Roe SM, Barford D. Molecular mechanism of target RNA transcript recognition by Argonauteguide complexes. Cold Spring Harb Symp Quant Biol 2006;71:45-50. [PubMed: 17381279]

Rajewsky N. microRNA target predictions in animals. Nat Genet 2006;38(Suppl):S8-13. [PubMed: 16736023]

Rigoutsos I. New tricks for animal microRNAS: targeting of amino acid coding regions at conserved and nonconserved sites. Cancer Res 2009;69:3245-8. [PubMed: 19351814]

Robins H, Li Y, Padgett RW. Incorporating structure to predict microRNA targets. Proc Natl Acad Sci U S A 2005;102:4006-9. [PubMed: 15738385]

Saetrom P, Snove O Jr, Rossi JJ. Epigenetics and microRNAs. Pediatr Res 2007;61:17R-23R.

Sasaki T, Shiohama A, Minoshima S, Shimizu N. Identification of eight members of the Argonaute family in the human genome small star, filled. Genomics 2003;82:323-30. [PubMed: 12906857]

Selbach M, Schwanhausser B, Thierfelder N, Fang Z, Khanin R, Rajewsky N. Widespread changes in protein synthesis induced by microRNAs. Nature 2008;455:58-63. [PubMed: 18668040]

Sethupathy P, Corda B, Hatzigeorgiou AG. TarBase: A comprehensive database of experimentally supported animal microRNA targets. RNA 2006;12:192-7. [PubMed: 16373484]

Smalheiser NR. Regulation of mammalian microRNA processing and function by cellular signaling and subcellular localization. Biochim Biophys Acta 2008a;1779:678-81. [PubMed: 18433727]

Smalheiser NR. Synaptic enrichment of microRNAs in adult mouse forebrain is related to structural features of their precursors. Biol Direct 2008b;3:44. [PubMed: 18957138]

Smalheiser NR, Lugli G. microRNA Regulation of Synaptic Plasticity. Neuromolecular Med. 2009

Su H, Trombly MI, Chen J, Wang X. Essential and overlapping functions for mammalian Argonautes in microRNA silencing. Genes Dev 2009;23:304-17. [PubMed: 19174539]

Tan GS, Garchow BG, Liu X, Yeung J, Morris JPt, Cuellar TL, McManus MT, Kiriakidou M. Expanded RNA-binding activities of mammalian Argonaute 2. Nucleic Acids Res. 2009a

Tan LP, Seinen E, Duns G, de Jong D, Sibon OC, Poppema S, Kroesen BJ, Kok K, van den Berg A. A high throughput experimental approach to identify miRNA targets in human cells. Nucleic Acids Res 2009b;37:e137. [PubMed: 19734348]

Vatolin S, Navaratne K, Weil RJ. A novel method to detect functional microRNA targets. J Mol Biol 2006;358:983-96. [PubMed: 16564540]

Wang WX, Rajeev BW, Stromberg AJ, Ren N, Tang G, Huang Q, Rigoutsos I, Nelson PT. The expression of microRNA miR-107 decreases early in Alzheimer's disease and may accelerate disease 
progression through regulation of beta-site amyloid precursor protein-cleaving enzyme 1. J Neurosci 2008;28:1213-23. [PubMed: 18234899]

Wang WX, Wilfred BR, Hu Y, Stromberg AJ, Nelson PT. Anti-Argonaute RIP-Chip shows that miRNA transfections alter global patterns of mRNA recruitment to microribonucleoprotein complexes. RNA 2010;16:394-404. [PubMed: 20042474]

Watanabe Y, Tomita M, Kanai A. Computational methods for microRNA target prediction. Methods Enzymol 2007;427:65-86. [PubMed: 17720479]

Wijnhoven BP, Michael MZ, Watson DI. MicroRNAs and cancer. Br J Surg 2007;94:23-30. [PubMed: 17205498]

Ying SY, Lin SL. MicroRNA: fine-tunes the function of genes in zebrafish. Biochem Biophys Res Commun 335:1-4. [PubMed: 16018965]

Zhang L, Ding L, Cheung TH, Dong MQ, Chen J, Sewell AK, Liu X, Yates JR 3rd, Han M. Systematic identification of C. elegans miRISC proteins, miRNAs, and mRNA targets by their interactions with GW182 proteins AIN-1 and AIN-2. Mol Cell 2007;28:598-613. [PubMed: 18042455]

Zhang R, Wang YQ, Su B. Molecular evolution of a primate-specific microRNA family. Mol Biol Evol 2008;25:1493-502. [PubMed: 18417486]

Zhao X, He X, Han X, Yu Y, Ye F, Chen Y, Hoang T, Xu X, Mi QS, Xin M, Wang F, Appel B, Lu QR. MicroRNA-Mediated Control of Oligodendrocyte Differentiation. Neuron 65:612-626. [PubMed: 20223198] 


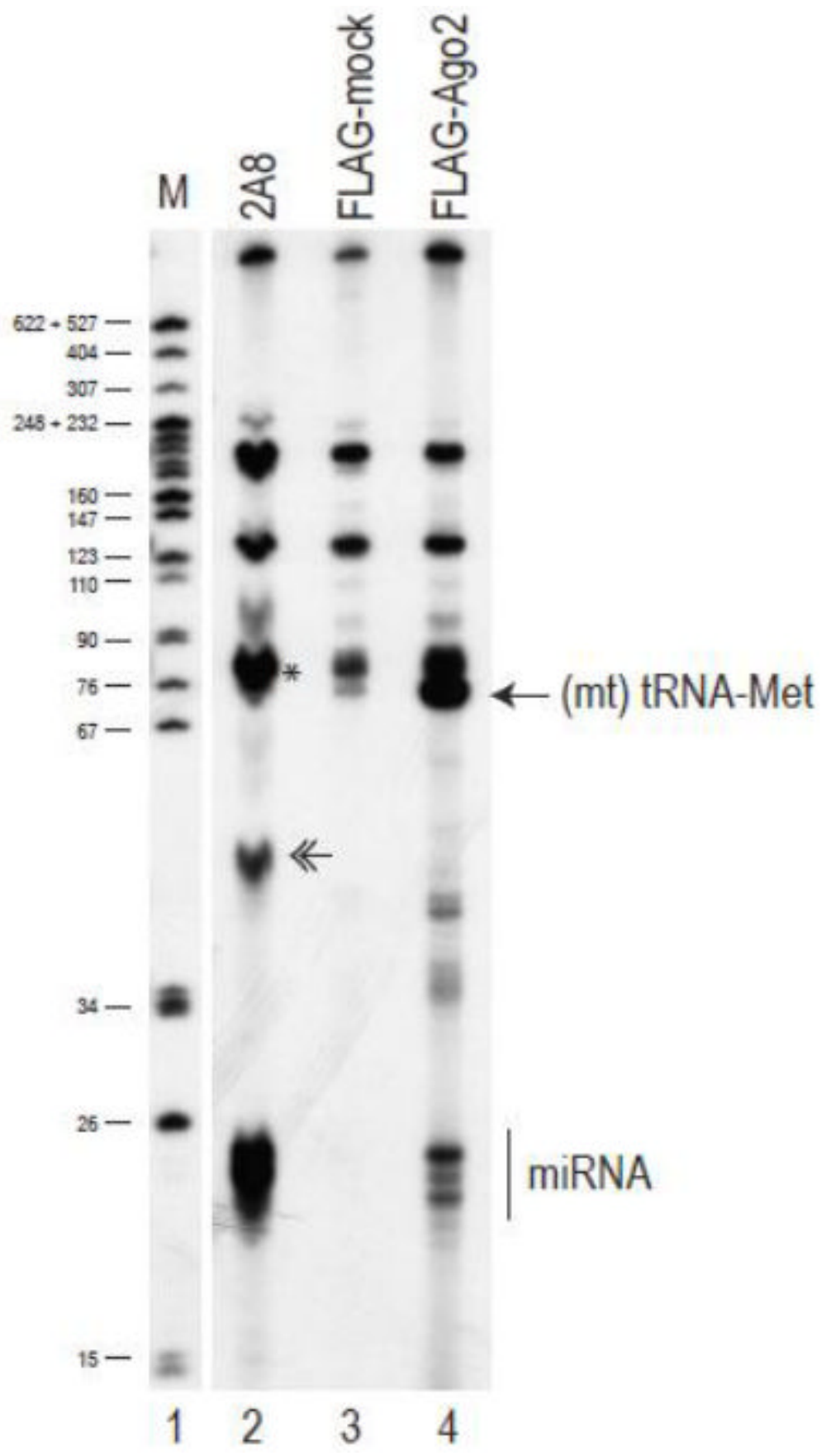

Figure 1.

Urea-PAGE gel showing 3'-end radiolabeled RNA after co-immunoprecipitation (Co-IP) experiments in human embryonic kidney $293 \mathrm{~T}$ cells. These experiments show that the levels of miRNAs loaded on overexpressed FLAG-tagged Ago2 are markedly reduced compared to miRNAs loaded onto endogenous Agos. Lane 1: Nucleotide marker. Lane 2: 2A8 RNA co-IP from nontransfected HEK 293T cells (2A8 antibody recognizes endogenous Agos). Double arrowhead is two microRNAs ligated together, an artifact after labeling with T4 RNA ligase and pCp. Asterisk shows pre-miRNAs (Tan et al., 2009a). Lane 3: anti-FLAG RNA co-IP from 293 cells transfected with empty FLAG vector (FLAG-mock). Lane 4: anti-FLAG RNA coIP from 293 T cells transfected with FLAG-AGO2. Note that the pattern of bands in Lane 4 is 
quite distinct from that in Lane 2. Specifically, there is an accentuated band (corresponding to [mt]tRNA-met) (Maniataki and Mourelatos, 2005), but by contrast the miRNA bands show much less RNA in the FLAG-AGO co-IP. 


\section{mRNAs changed in Anti-AGO RIP-Chip experiments in $\mathrm{H} 4$ tumor cells}

180

160

140

120

100

80

Figure 2.

Chart shows the number of mRNAs with at least 4-fold change in AGO-miRNP (red) and lysate (blue) after specific mIRNA transfections. This provide some idea about the "downstream" effects of some miRNAs and how individual miRNAs can have distinct effects. Experiments were performed in H4 cells, a "glioneuronal" tumor cell line. All experiments were performed in triplicate as described in detail previously (Wang et al., 2010). Note that for miR-107 and miR-124, many more mRNAs are downregulated after miRNA transfection than are knocked down in the lysate; however, for miR-320 this tendency is reversed. These data indicate that individual miRNAs may act via different mechanisms. Fold-changes were determined with respect to a transfected miRNA relative to control miRNA. 


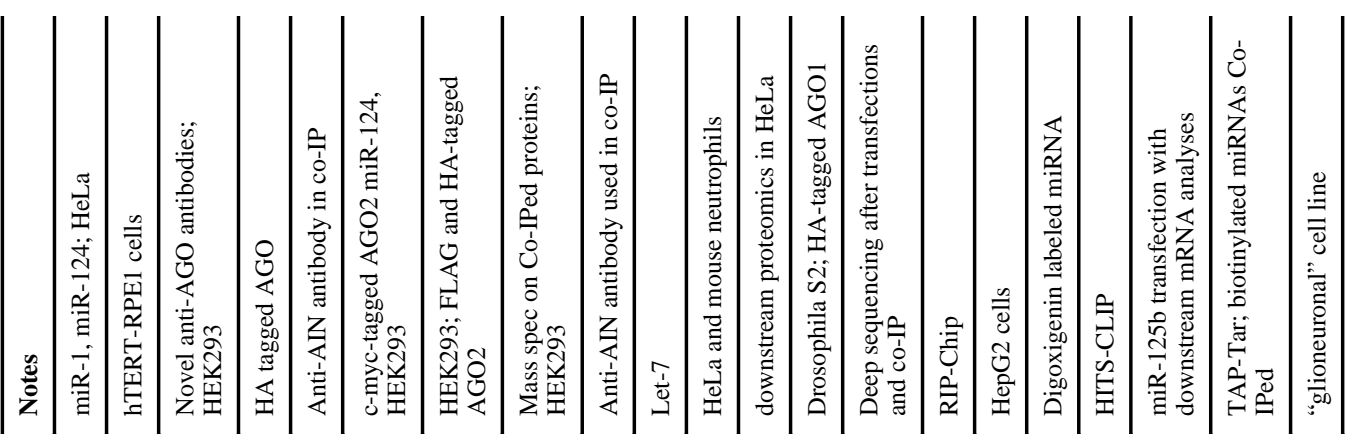

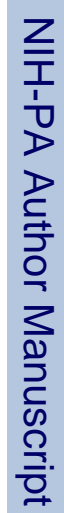
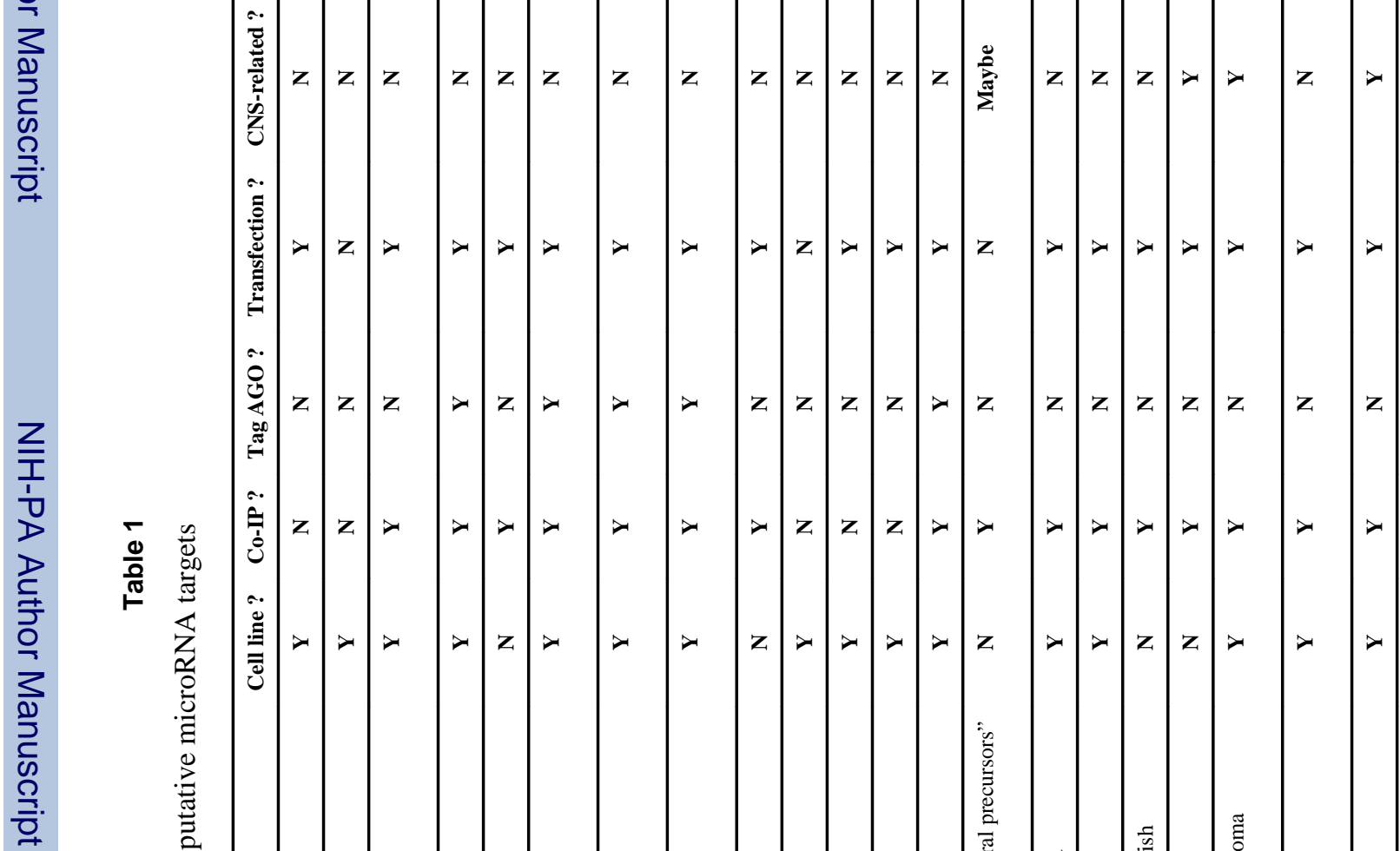

ב
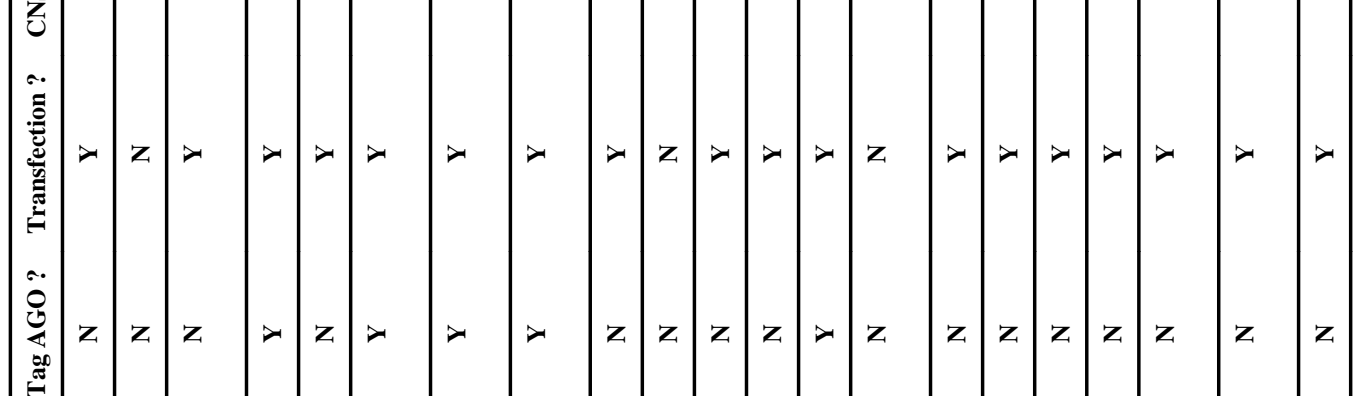

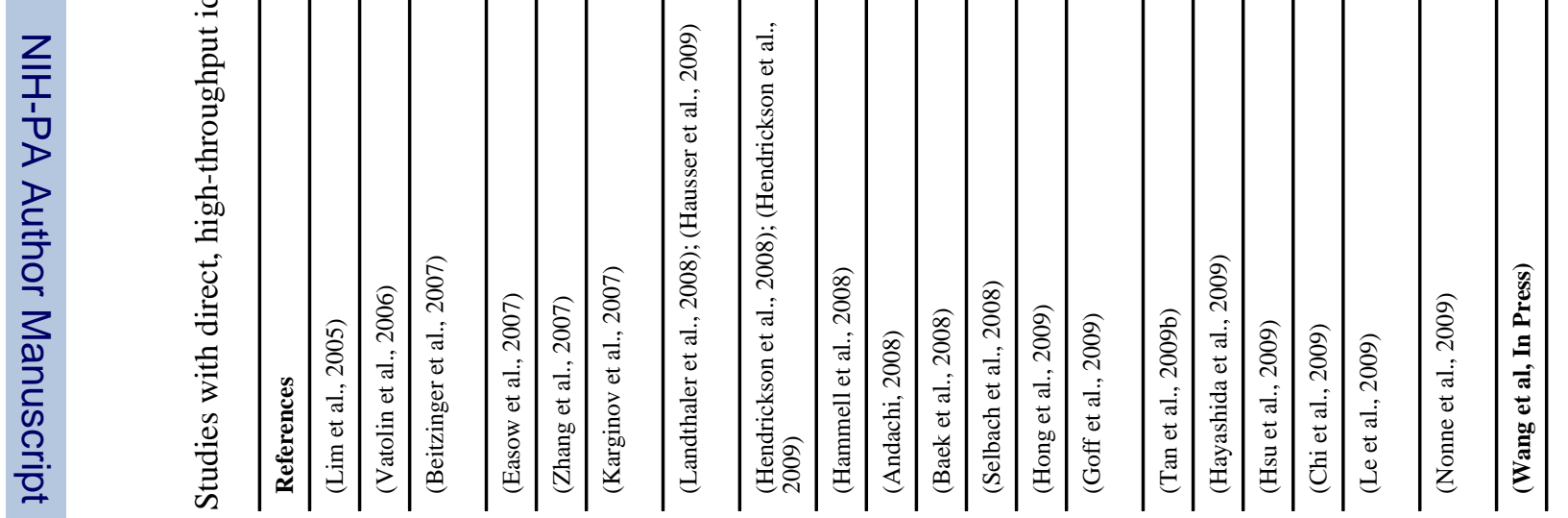

